\title{
Benthic phosphorus and iron budgets for three NW African slope sediments: a balance approach
}

\author{
K. Küster-Heins ${ }^{1}$, G. J. de Lange ${ }^{2}$, and M. Zabel ${ }^{3}$ \\ ${ }^{1}$ Department of Geosciences, University of Bremen, Klagenfurter Strasse, 28359 Bremen, Germany \\ ${ }^{2}$ Department of Earth Sciences - Geochemistry, Faculty of Geosciences, Utrecht University, 3508 TA Utrecht, \\ The Netherlands \\ ${ }^{3}$ Marum - Center for Marine Environmental Sciences, University of Bremen, Leobener Strasse, 28359 Bremen, Germany \\ Received: 13 May 2009 - Published in Biogeosciences Discuss.: 29 May 2009 \\ Revised: 22 January 2010 - Accepted: 26 January 2010 - Published: 3 February 2010
}

\begin{abstract}
Despite intensive research on the different domains of the marine phosphorus $(\mathrm{P})$ cycle during the last decades, frequently discussed open questions still exist especially on controlling factors for the benthic behaviour of $P$ and its general distribution in sediment-pore water systems. Steady state or the internal balance of all relevant physical and (bio)geochemical processes are amongst the key issues. In this study we present and discuss an extended data set from surface sediments recovered from three locations on the NW African continental slope. Pore water data and results from sequential sediment extractions give clear evidence to the well-known close relationship between the benthic cycles of $\mathrm{P}$ and iron. Accordingly, most of the dissolved phosphate must have been released by microbially catalyzed reductive dissolution of iron (oxhydr)oxides. However, rates of release and association of $\mathrm{P}$ and iron, respectively, are not directly represented in profiles of element specific sediment compositions. Results from steady-state based transport-reaction modelling suggest that particle mixing due to active bioturbation, or rather a physical net downward transport of $\mathrm{P}$ associated to iron (oxyhydr)oxides, is an essential process for the balance of the inspected benthic cycles. This study emphasizes the importance of balancing analytical data for a comprehensive understanding of all processes involved in biogeochemical cycles.
\end{abstract}

\section{Introduction}

Marine sediments are the largest reservoirs of $\mathrm{P}$ on Earth (e.g. Van Cappellen and Ingall, 1994). In particular, continental shelf and upper slope sediments are important sinks

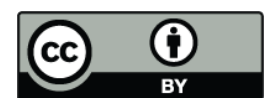

Correspondence to: K. Küster-Heins (snoepje@uni-bremen.de) for major biogeochemical elements, like carbon, nitrogen and $P$. These regions are generally characterized by a large input of organic material through vertical settling from the euphotic zone and lateral transport (e.g. Jahnke et al., 1989; Kim et al., 1999; Inthorn et al., 2006). For the most part, the particulate organic material is already decomposed during its pathway through the water column. However, a minor but important portion arrives at the sea floor where microbial degradation processes continue and lead to the release of dissolved phosphate into bottom and interstitial waters. Following the burial pathway, the sequence of early diagenetic reactions seems to dominate the benthic $\mathrm{P}$ cycle and therefore the distribution of $\mathrm{P}$ in marine sediments. Here a variety of environmental conditions, geochemical and biogeochemical processes determine how much $\mathrm{P}$ is released back to the oceans nutrient cycle or is buried for geological periods of time.

During the last decades, the number of studies looking on different, specific parts of the benthic P cycle has multiplied. Such studies ranged from regional to global distribution of phosphatic sediments and rocks (e.g. Baturin, 1982; Föllmi, 1996), to investigations on the recent formation of phosphorites (e.g. Froelich et al., 1988; Schenau et al., 2000; Schulz and Schulz, 2005), from detailed inspections of the benthic $P$ cycle on local and regional scales (e.g. Sundby et al., 1992; Ingall and Jahnke, 1994; Anschutz et al., 1998) to basin-wide quantifications of the benthic phosphate release (Zabel et al., 1998; Hensen et al., 1998), from the identification and quantification of $\mathrm{P}$ forms in marine sediments (e.g. De Lange, 1992; Ruttenberg, 1992; Schenau and De Lange, 2000) to steady-state modelling of the sediment-pore water system with special focus on the behaviour of P (e.g. Slomp et al., 1996, 1998). In addition, it has long been recognized that iron $(\mathrm{Fe})$ plays an important role in binding of phosphates in sediments (e.g. Krom and Berner, 1981; Sundby et al. 1992;

Published by Copernicus Publications on behalf of the European Geosciences Union. 


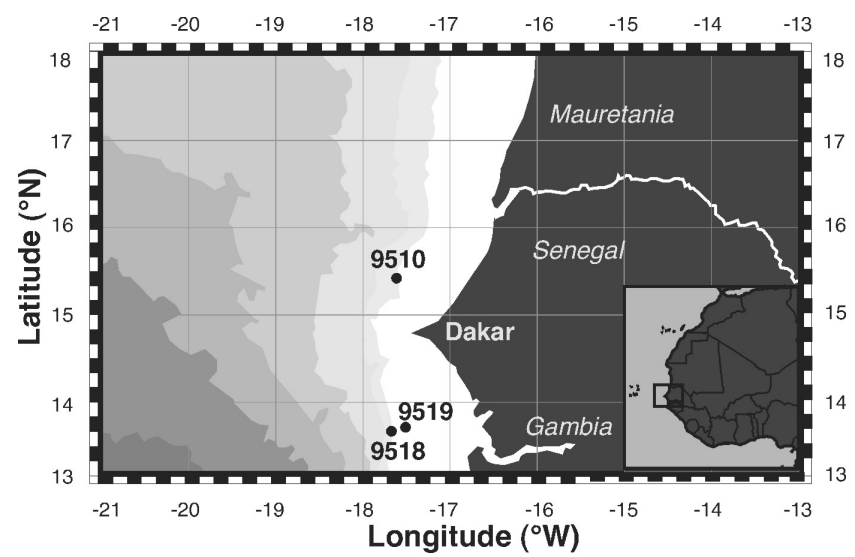

Fig. 1. Sampling locations along the NW African continental margin. Water depth at site GeoB 9510: $1567 \mathrm{~m}$, GeoB 9519: $1488 \mathrm{~m}$, and GeoB 9518: $1997 \mathrm{~m}$.

Jensen et al., 1995; Slomp et al., 1998). These studies have resulted in an improved understanding of $\mathrm{P}$ cycling in marine sediments. However, nearly all of them have focused on specific subdomains without taking the total balance of the benthic system into account. Certainly, for example Sundby et al. (1992) have derived a general scheme of the interrelating processes of the benthic $\mathrm{P}$ fluxes, but release and precipitation rates have not been used to balance corresponding mass transfers. In this regard, the combination of analytical results with steady-state transport- reaction modelling, which have been carried out by Slomp et al. $(1996,1998)$, can be seen as the most complete one. However, focusing on the authigenic formation of apatite and the role of $\mathrm{P}$ adsorption in shallow water sediment, respectively, the importance of bioturbation for the balance of the benthic $\mathrm{P}$ cycle has been discussed only marginally. For this study, we investigated the $\mathrm{P}$ geochemistry at three sites on the continental margin of NW Africa. An extensive data set with varying analyses of pore waters and sediments was generated for the purposes (1) to unravel the local geochemical conditions that control the benthic $\mathrm{P}$ and Fe cycles, and (2) to identify, understand and quantify the processes that affect the (re)distribution of $\mathrm{P}$ in surface sediments.

\section{Material and methods}

\subsection{Study area and sampling sites}

We present results from sediment investigations on three cores, recovered from 1488 to $1997 \mathrm{~m}$ water depth during RV Meteor cruise leg M65/1 along the northwestern African continental margin (Mulitza et al., 2006; Fig. 1). In this region, seasonal variations of northeast trade wind position and intensity control the westward directed transport of near-shore surface waters (Canary Current; e.g. Mittelstaedt, 1983;
Helmke et al., 2005). The Canary Current, a broad eastern boundary current, flows from Morocco southward toward the Cape Verde Islands, where it joins the westward flowing North Equatorial Under Current and primary South Atlantic Central Water (McMaster and Lachance, 1969; Helmke et al., 2005). The South Atlantic Central Water is the main source of nutrient-rich water masses, leading to a $50-70 \mathrm{~km}$ wide coastal band of intensive upwelling (Hagen, 1981, 2000; Lutze and Coulbourn, 1984; Helmke et al., 2005). The northern-most site GeoB 9510 is located between the Senegal River and Dakar, where terrigenous silty-clayey muds dominate (Barusseau et al., 1988; Mulitza et al., 2006). GeoB sites 9519 and 9518 are located slightly south between Dakar and the Gambia River. Here terrigenous sandy muds are abundant along the coast. Off Senegal, relatively low carbonate contents of 8.1 to $13.5 \mathrm{wt} \%$ are indicative of the dominance of land-derived material in these sediments (e.g. McMaster and Lachance, 1969; Hartmann et al., 1976). According to Summerhayes (1983), the relatively low contents of organic carbon in the studied surface sediments (2.4-2.9 wt\%; Fig 5a) are the result of intensive turbulence and turbidity, which favour intense recycling of biogenic compounds already in the water column. Besides, in a recent study by Mollenhauer et al. (2007) significant differences in radiocarbon contents are observed in sediments off NW Africa. Accumulated organic material is older than the vertically settled original biogenic debris, caused by resuspension in the water column by lateral transport processes across the shelf.

\subsection{Sediment and pore water sampling}

Sediment cores were taken with a multicorer and processed under in situ temperature $\left(4^{\circ} \mathrm{C}\right)$ directly upon retrieval. At all sites Teflon pore water squeezers were used (Schulz, 2006a), subsequently operated in a glovebox with argon at a pressure gradually increasing up to 5 bar. The pore water was retrieved through $0.2 \mu \mathrm{m}$ cellulose acetate filters. In addition, at sites GeoB 9519 and 9518, rhizon samplers (pore size $0.1 \mu \mathrm{m}$ ) were used (Seeberg-Elverfeldt et al., 2005; Dickens et al., 2007).

Solid phase samples for total digestions and sequential extraction were sectioned at $0.5-5 \mathrm{~cm}$ intervals and stored at $-20{ }^{\circ} \mathrm{C}$.

\subsection{Pore water analyses and flux calculations}

Pore water analyses were carried out on board within a few hours after pore water sampling: alkalinity (by titration; Anderson et al., 1999), ammonium (via conductivity; Hall and Aller, 1992), phosphate (photometrically; Strickland and Parsons, 1972), ferrous iron (photometrically; Koroleff and Kremling, 1999) and nitrate (photometrically; Hansen and Koroleff, 1999). Aliquots of the remaining pore water samples were diluted 1:10 with demineralized water and acidified with $1 \% \mathrm{HNO}_{3 \text { (suprapure) }}$ for preservation and 
Table 1. Sequential extraction steps (after Ruttenberg, 1992; Schenau and De Lange, 2000; Latimer et al., 2006). After each step, the extraction/washing solutions were centrifuged and filtered $(0.2 \mu \mathrm{m})$.

\begin{tabular}{|c|c|c|}
\hline Step & Reagents & P component extracted \\
\hline (1) Biogenic & $25 \mathrm{~mL}_{2} \mathrm{M} \mathrm{NH}_{4} \mathrm{Cl}(\mathrm{pH} 7)$ & $\begin{array}{l}\text { exchangeable } \mathrm{P} \text {, biogenic } \\
\text { apatite, apatite precursor } \\
\text { mineral, } \mathrm{CaCO}_{3} \text {-bound } \mathrm{P}\end{array}$ \\
\hline (2) $\mathrm{Fe}(\mathrm{III})$-bound & 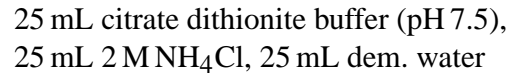 & $\begin{array}{l}\text { adsorbed and reducible/ } \\
\text { reactive } \mathrm{Fe}(\mathrm{III}) \text {-bound } \mathrm{P}\end{array}$ \\
\hline (3) Authigenic & $\begin{array}{l}25 \mathrm{~mL} 1 \mathrm{M} \mathrm{Na} \text {-acetate ( } \mathrm{pH} 4) \text {, } \\
25 \mathrm{~mL} 2 \mathrm{M} \mathrm{NH}_{4} \mathrm{Cl}, 25 \mathrm{~mL} \text { dem. water }\end{array}$ & authigenic apatite \\
\hline (4) Detrital & $\begin{array}{l}25 \mathrm{~mL} 1 \mathrm{M} \mathrm{HCl} \\
25 \mathrm{~mL} \mathrm{dem} . \text { water }\end{array}$ & detrital P \\
\hline (5) Organic-bound & $\begin{array}{l}\text { after ignition at } 550^{\circ} \mathrm{C} \\
25 \mathrm{~mL} 1 \mathrm{M} \mathrm{HCl}\end{array}$ & organic $\mathrm{P}$ \\
\hline (6) Opal-bound & $25 \mathrm{~mL} 1.5 \mathrm{M} \mathrm{NaOH}$ at $85^{\circ} \mathrm{C}$ & opal-associated P \\
\hline
\end{tabular}

stored at $4{ }^{\circ} \mathrm{C}$. Diluted squeezer samples were used for subsequent analysis of total sulphur at the University of Bremen using an inductively coupled plasma atomic emission spectrometer (ICP-OES, Perkin Elmer Optima 3000).

The diffusive transport rates of dissolved phosphate and ferrous iron were determined by applying Fick's 1st Law of diffusion: molecular flux $(J)=-\varphi \cdot D_{0} \cdot\left(1-\ln \left(\varphi^{2}\right)\right)^{-1}$. $\partial \mathrm{C} / \partial x$ (Schulz, 2006a). The porosity $(\varphi)$ is assumed to be constant at 0.8 (Mulitza et al., 2006), the diffusion coefficient $\left(D_{0} 4{ }^{\circ} \mathrm{C}\right.$ ) is $123 \mathrm{~cm}^{2} \mathrm{a}^{-1}$ and $124 \mathrm{~cm}^{2} \mathrm{a}^{-1}$ for phosphate ( $\mathrm{Li}$ and Gregory, 1974) and ferrous iron (Lerman, 1979), and $\partial \mathrm{C} / \partial x$ reflects the specific concentration gradient. For modelling of pore water concentration profiles, the computer model Explicite was used (Zabel and Schulz, 2001; Schulz and Schulz, 2005; Schulz, 2006b), which provides a numerical solution of Fick's 2nd Law. Balancing of the systems base on the simplification of a constant dry bulk density of $0.4 \mathrm{~g} \mathrm{~cm}^{-3}$ (Sarnthein, 2004).

\subsection{Solid phase analysis}

Bulk concentrations of major elements in sediments were determined after total digestion in a $\mathrm{HNO}_{3}(65 \%), \mathrm{HCl}(30 \%)$ and HF (47-51\%) mixture using a Microwave system (Zabel et al., 1999). Dissolved elemental concentrations of $\mathrm{P}, \mathrm{Fe}$ and sulphur (S) were measured with ICP-OES. Application of standard reference material (USGS standard MAG-1, inhouse standard MAX) assured the accuracy, as the element concentration were within certified range. So, for all ICPOES measurements the precision of analyses was $<5 \%$.
The solid-phase speciation of $\mathrm{P}$ in the sediments was examined using a five-step sequential extraction scheme, where approximately $0.125 \mathrm{~g}$ of oven-dried $\left(105^{\circ} \mathrm{C}\right)$ and ground (in an agate mortar) sediment sample was washed with $25 \mathrm{~mL}$ (1) $2 \mathrm{M} \mathrm{NH}_{4} \mathrm{Cl}$ ( $\mathrm{pH} 7$; step repeated ten times), (2) citrate dithionite buffer (CDB; pH 7.5), (3) $1 \mathrm{M}$ sodium acetate buffer (pH 4), (4) $1 \mathrm{M} \mathrm{HCl}$, and (5) $1 \mathrm{M} \mathrm{HCl}$ after ignition at $550^{\circ} \mathrm{C}$. After step (2) and (3) samples were rinsed suc-

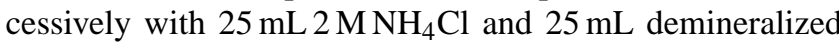
water to prevent the re-adsorption of phosphate (washing step). After each step, the extraction and washing solutions were centrifuged and filtered $(0.2 \mu \mathrm{m}$ membranefilter $)$. The extraction scheme is after Ruttenberg (1992) and Schenau and De Lange (2000) (Table 1). Comparing the sum of extracted $\mathrm{P}$ and the separately determined total-P content of the sediment, good to fair correspondence was obtained for cores 9510 and 9519 (recovery of 99 and $90 \%$, respectively), whereas there was a substantial difference for core 9518 (recovery of $83 \%$; Fig. 3). Therefore, residues for the latter sediments were additionally extracted with (6) $25 \mathrm{~mL} 1.5 \mathrm{M}$ sodium hydroxide solution at $85^{\circ} \mathrm{C}$, to determine the opalassociated $\mathrm{P}$ fraction according to Latimer et al. (2006) (Table 1). Despite of the recovery of a significant fraction of opal-associated $\mathrm{P}$, most of the discrepancy remained for this core. The concentration of $\mathrm{P}$ released to each leaching solution was quantified automatically with a Skalar Autoanalyser (SA 6250) at $880 \mathrm{~nm}$, except P and Fe (i.e. associated with iron (oxyhydr)oxides) concentration in the CDB solutions and opal-associated $\mathrm{P}$, which were determined with ICP-OES. Similar deficits of extractions against total contents in marine sediments have been attributed to systematic errors in the measurements of the low $\mathrm{P}$ concentrations with ICP-OES (Schenau and De Lange, 2001). Another critical point concerns on the pretreatment of samples. Generally, AVS and CRS mineral phases from anoxic sediment layers (both containing associated ferrous iron) could be oxidized. 
Certainly, De Lange (1992) has described the corresponding effect on results from a very similar extraction protocol as negligible for anoxic deep-sea sediments, but more recently just the opposite was observed for organic-rich peat soils (Schlichting and Leinweber, 2002). Our results show that an increasing amount of sulphur containing minerals exist below a depth of 5 to $6 \mathrm{~cm}$ and we cannot exclude that a minor portion could have been oxidized during oven-drying. As a consequence, fractions of reducible iron $\left(\mathrm{Fe}_{\mathrm{CDB}}\right)$ and $\mathrm{Fe}(\mathrm{III})$-bound $\mathrm{P}\left(\mathrm{P}_{\mathrm{CDB}}\right)$ would be overestimated slightly.

Total organic carbon (TOC) and total carbon $\left(\mathrm{C}_{\text {tot }}\right)$ were analysed on dried and ground samples with a Leco CS 200. This was done by analysing the untreated and decarbonated (using $12.5 \% \mathrm{HCl}$ ) samples, $\% \mathrm{CaCO}_{3}$ being the difference between these two, was calculated as: $\mathrm{CaCO}_{3}(\%)=\left(\mathrm{C}_{\text {tot }^{-}}\right.$ TOC) $\cdot 8.33$. Several standards with $\mathrm{C}$ contents of $0.8-12 \%$ were applied to maintain accuracy within a range of $1 \%$.

For each core sub-samples from $0-0.5,4-5,7.5-10,15-$ $20 \mathrm{~cm}$ sediment depth were used for radiocarbon dating of TOC following standard procedures (Leibniz-Labor AMS facility at the Christian-Albrechts University Kiel, Germany; Nadeau et al., 1997).

\section{Results}

\subsection{Pore water geochemistry}

Pore water results reflect the distribution of major diagenetic compounds expected during the general early oxidation sequence of organic matter in the upper sediment column (Fig. 2). The nitrate concentration increases from the bottom water value $\left(23-26 \mu \mathrm{mol} \mathrm{L}^{-1}\right)$ to a maximum (30$39 \mu \mathrm{mol} \mathrm{L}^{-1}$ ) close to the sediment water interface at all three investigated sites. Figure 2 shows that no significant differences were detected between both pore water extraction methods for nitrate and ammonia concentrations at site GeoB 9519. At site GeoB 9518 nitrate concentration is even higher and ammonia concentrations lower in squeezer samples when compared to results obtained with rhizons. Certainly this difference could reflect the natural, spatial heterogeneity in nitrification intensity, but is also explainable by an artificial release of nitrate due to a mechanical crushing of macrobenthic organisms during the squeezing process, or by artificial, microbial oxidation of ammonia in the chamber of the squeezer. Lower ammonium concentrations in squeezer samples may give support to the last presumption. In this context, it has to be mentioned that nitrifying bacteria are considered to be strictly aerobic and therefore depend on adequate oxygen supply for their energy gain. So, ammonia oxidation would cast first suspicion on the influence of oxygen during pressure filtration. However, nitrate penetration depths show no differences. Like expected, ammonium and alkalinity show the normal gradual increase with increasing sediment depth. In squeezer samples ammonium increases from a concentration of 4.3 and $14.9 \mu \mathrm{mol} \mathrm{L}^{-1}$ at $\mathrm{GeoB} 9519$ and GeoB 9518, respectively, to a concentration of 68.4 to $72.1 \mu \mathrm{mol} \mathrm{L}^{-1}$. In rhizon samples gradients have nearly the same slopes. Total sulphur, or rather sulphate concentrations (no sulphide could be detected) keeps almost constant throughout the core lengths.

All three cores show pronounced peaks in ferrous iron, clearly indicating zones of reductive dissolution of iron (oxyhydr)oxides at depth of 3 to $7 \mathrm{~cm}$. Parallel to the increase in ferrous iron, phosphate concentrations increase up to $22.4 \mu \mathrm{mol} \mathrm{L}^{-1}$ (Fig. 2). Most remarkable, for both ferrous iron and phosphate much higher concentration levels occurred when gained with rhizons (i.e. GeoB 9519 and 9518). Differences get most impressive when integrating measured values over core depth. Up to 6 times more dissolved $\mathrm{Fe}$ (II) was detected with rhizon sampling when compared to squeezer samples. For phosphate, about twice as much was determined in the upper $20 \mathrm{~cm}$ of these sediments. Apparently, also because there is no indication to assume a stimulation of iron and phosphate release by rhizon sampling, the reduction of concentrations of both constituents has occurred during pore water extraction by pressure filtration. The most obvious cause is oxidation of reduced species by residues of free oxygen in filters, tubes or thin flow channels within the squeezers itself. Especially ferrous iron is known to be highly sensitive to even very low oxygen concentrations (e.g. De Lange et al., 1992). The phosphate concentrations are affected as well, due to the strong affinity of phosphate to adsorb on iron (oxyhydr)oxide and the resulting co-precipitation. The assumed artificial ammonia oxidation, discussed above as responsible for differences in nitrate concentrations, gives support to this interpretation. This first comparison of squeezer data with rhizon samples may therefore reveal the limitation of the squeezing procedure during intensive sample campaigns when time is not sufficient to guarantee completely oxygen-free conditions until sensible components could be conserved or analyzed. All together, we want to emphasize that all indications give clear evidence that measured values for redox-sensitive parameters and associated components on our squeezed samples may be incorrect. All other parameters are not affected. This observation became only possible by the simultaneous application of both methods.

\subsection{Sediment composition}

In all three sedimentary settings, profiles of bulk $\mathrm{P}$ exhibit local maxima of $0.82-0.96 \mathrm{~g} \mathrm{~kg}^{-1}$ around $2 \mathrm{~cm}$ sediment depth (Fig. 3). Below these enrichments, data reveal decreases of about $14-22 \%$. According to the results of the sequential extraction procedure, $0.62-0.87 \mathrm{~g} \mathrm{P} \mathrm{kg}^{-1}$ could be assigned to specific carrier phases, which corresponds to a recovery of 83-99\% of the total P content in these sediments (Fig. 3). The fractions of $\mathrm{Fe}(\mathrm{III})$-bound $\mathrm{P}$, biogenic $\mathrm{P}$, and organicbound $\mathrm{P}$ (steps 1, 2 and 5) are nearly equivalent. However 

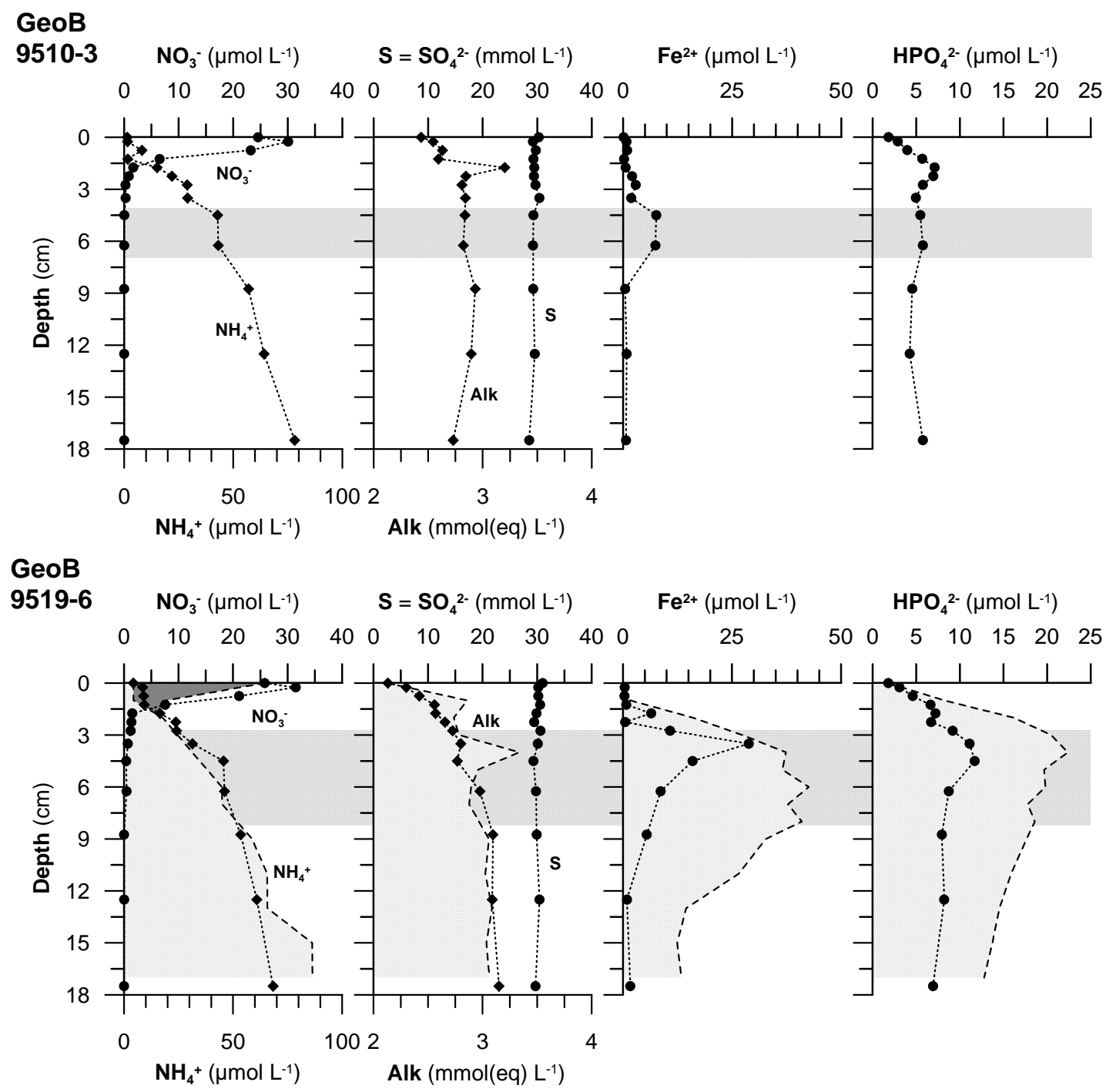

GeoB

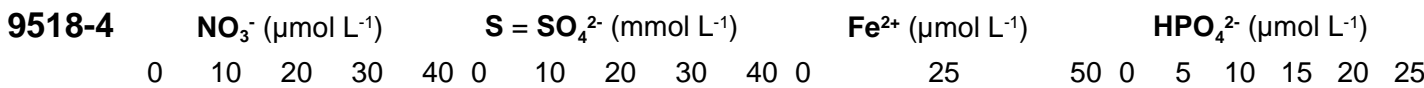

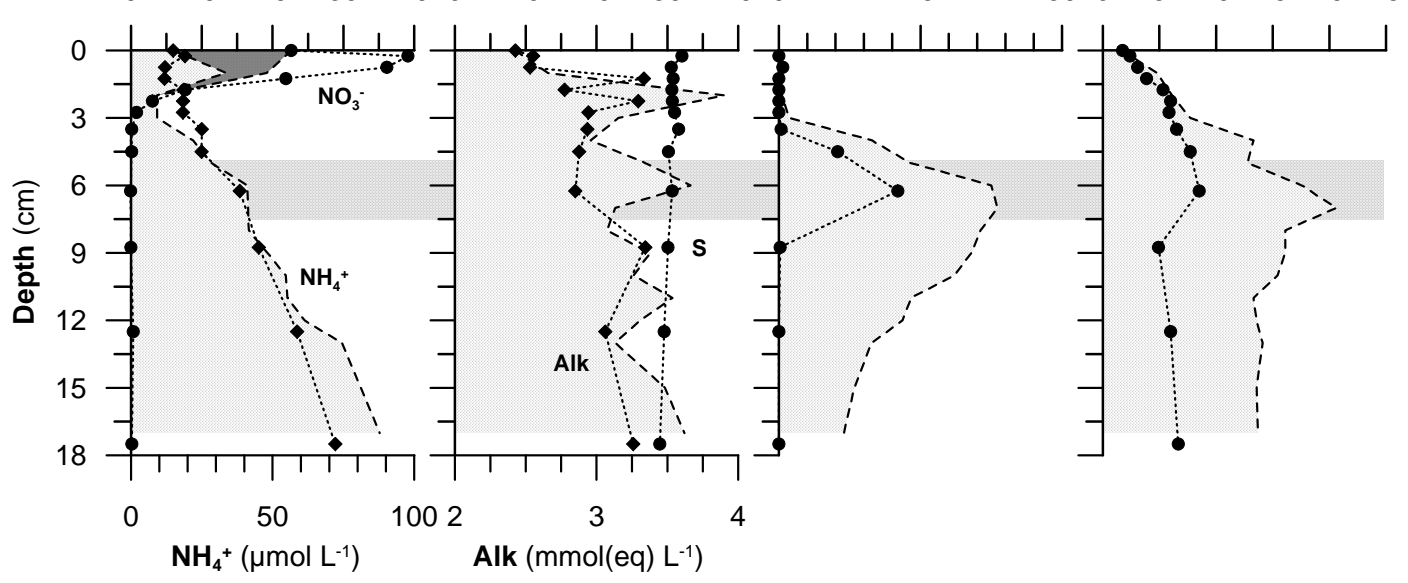

Fig. 2. Depth profiles of dissolved constituents. Dotted lines: concentration measured in squeezer samples; dashed lines and light-grey shaded areas: concentration measured in rhizon samples; grey bars mark the approximate zone where iron (oxyhydr)oxides are reductively dissolved. 


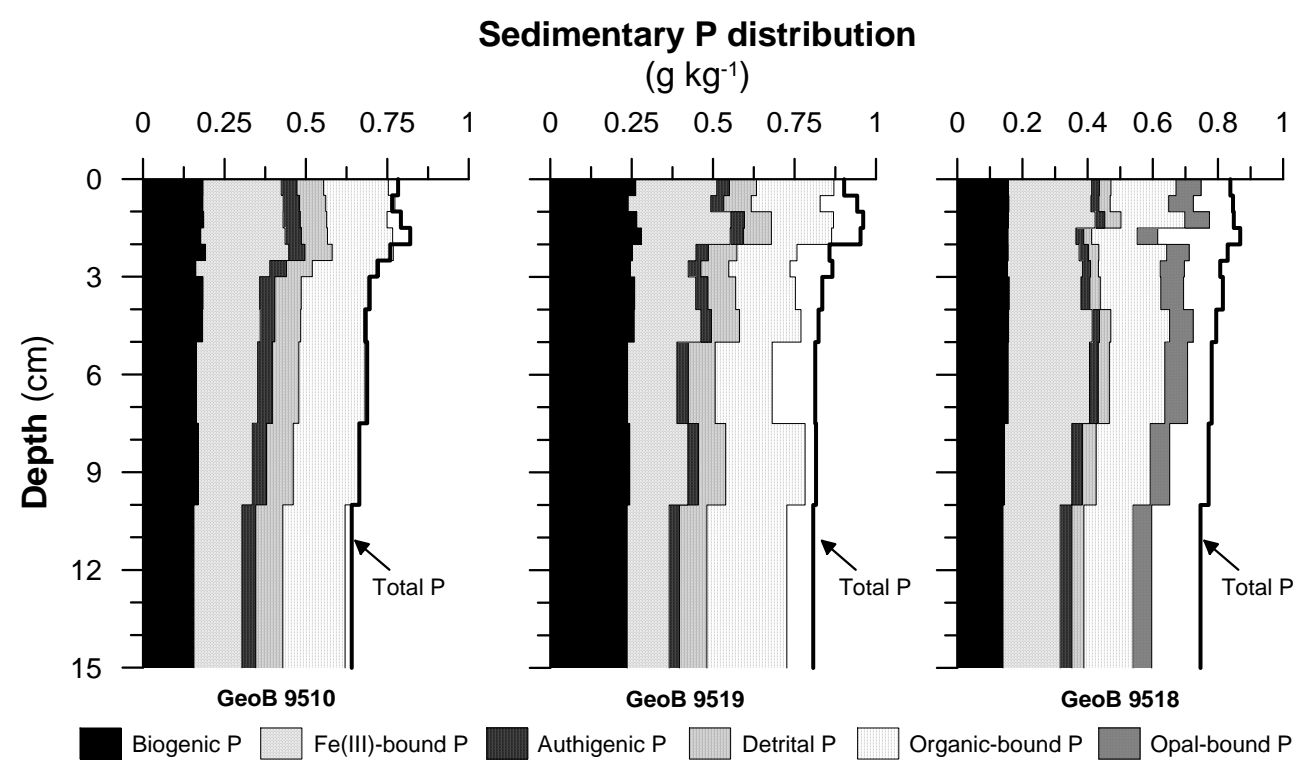

Fig. 3. Sedimentary $\mathrm{P}$ distribution ( $\mathrm{g} \mathrm{kg}^{-1}$ dry sediment), as deduced from sequential extraction of biogenic, Fe(III)-bound, authigenic, detrital, organic-bound and opal-bound $\mathrm{P}$ (the latter only for GeoB 9518) compared to bulk P content.

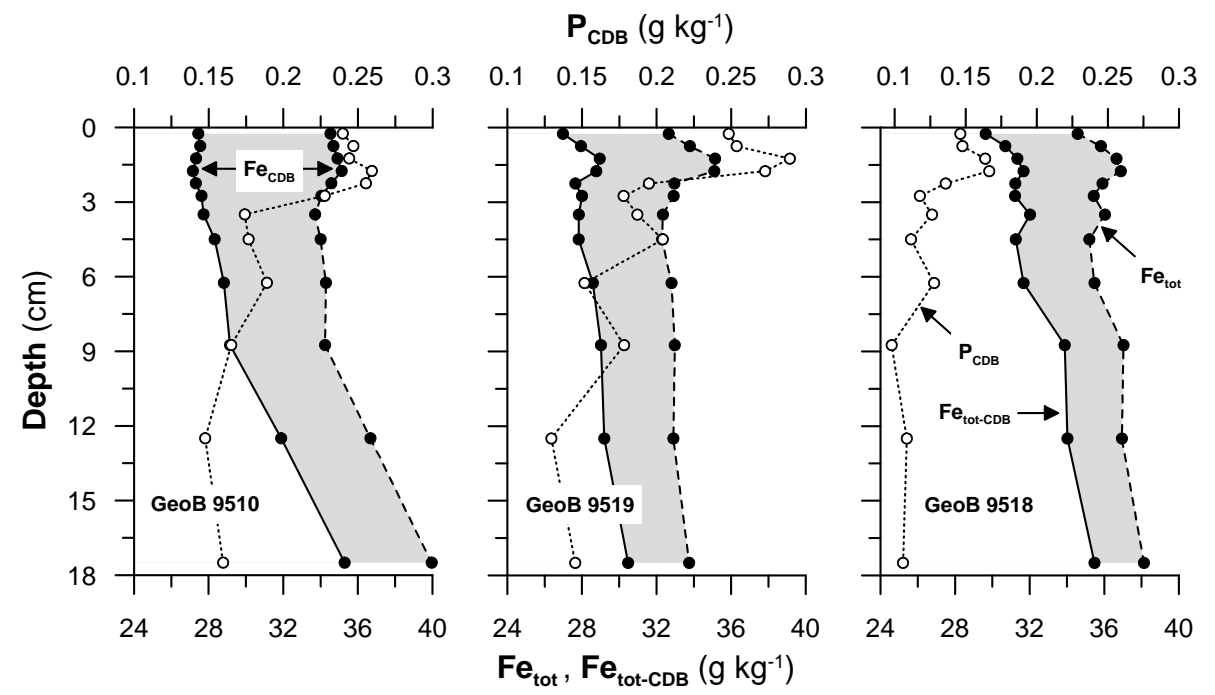

Fig. 4. Distributions of $\mathrm{CDB}$ extractable $\mathrm{P}\left(\mathrm{P}_{\mathrm{CDB}}\right.$, dotted lines with open symbols), bulk Fe content ( $\mathrm{Fe}_{\text {tot }}$, dashed lines), and $\mathrm{Fe}_{\text {tot }}$ minus $\mathrm{Fe}_{\mathrm{CDB}}\left(\mathrm{Fe}_{\mathrm{tot}-\mathrm{CDB}}\right.$, solid lines). The light-grey shaded areas represent the $\mathrm{Fe}_{\mathrm{CDB}}$ contents, which show maxima at about $2 \mathrm{~cm}$ sediment depth (cf. Fig. 5d) and decreases towards core bottom. All values are given in $\mathrm{g} \mathrm{kg}^{-1}$ dry sediment.

the ratios between these three pools change with sediment depth. While the proportion of biogenic P (step 1) remains relatively constant, the $\mathrm{Fe}$ (III)-bound fraction (step 2) and the organic-bound P (step 5) seem to be negatively correlated, with significant higher values for the oxide fraction close to the sediment surface. Compared with the main fractions, the authigenic, detrital and opal-bound $\mathrm{P}$ fractions are negligible (Fig. 3). Only subtle differences appear to occur for the dominant P-carrying phases between the three cores.
The total sedimentary Fe concentrations $\left(\mathrm{Fe}_{\text {tot }}\right)$ are in the range of $33.3-40.0 \mathrm{~g} \mathrm{~kg}^{-1}$ (Fig. 4). Apart from a general increase by $3-16 \%$ between the surface layer and the core bottom, prominent local maxima exist at about $1.5-2.0 \mathrm{~cm}$ sediment depth. These characteristic features are mainly caused by iron (oxyhydr)oxides (i.e. $\mathrm{Fe}_{\mathrm{CDB}}$, step 2 ) which increase to $5-8 \mathrm{~g} \mathrm{~kg}^{-1}$ or $15-23 \%$ of the total Fe content. Below this enrichment layer the $\mathrm{Fe}_{\mathrm{CDB}}$ fractions decrease by 21-29\% within narrow depth intervals of $2 \mathrm{~cm}$ only (Figs. 4 and 5d). The total decrease of CDB extractable Fe fraction 


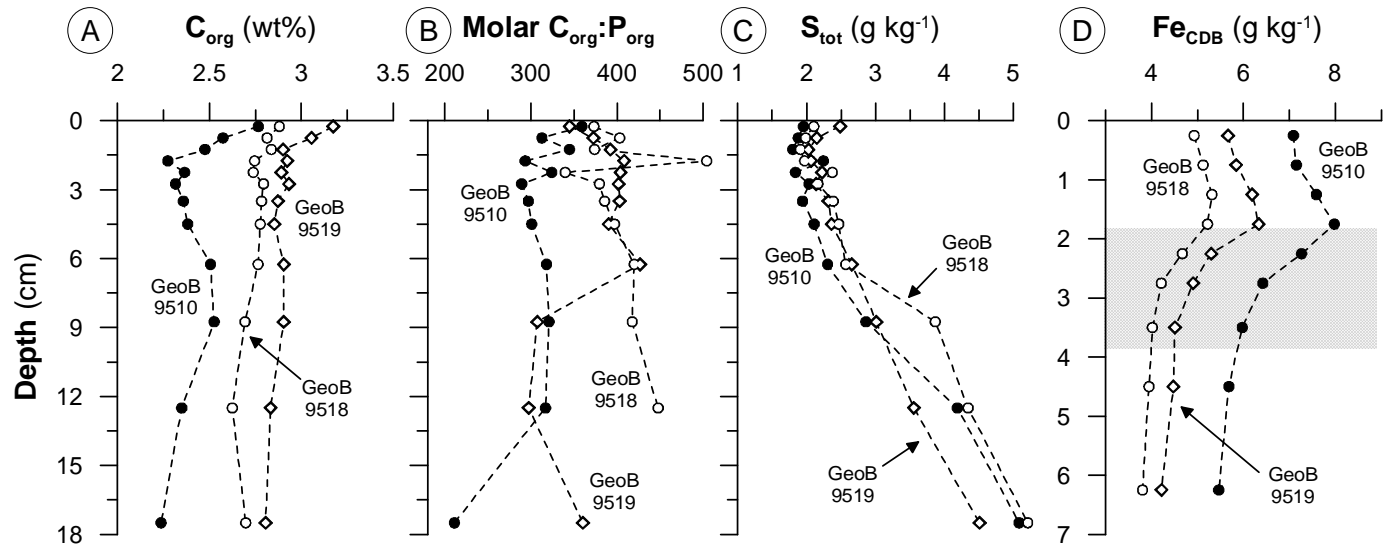

Fig. 5. (A) Depth profiles of total organic carbon content $\left(\mathrm{C}_{\text {org }}\right.$ in wt $\left.\%\right)$, (B) molar $\mathrm{C}_{\mathrm{org}}: \mathrm{P}_{\text {org }}$ ratios (relation between $\mathrm{C}_{\text {org }}$ and organic-bound $\mathrm{P})$, (C) depth profiles of bulk S, and (D) depth profiles of the upper $7 \mathrm{~cm}$ sediment column of CDB extractable Fe content for each GeoB site. The shaded area in panel 5D highlights the significant decreases in $\mathrm{Fe}_{\mathrm{CDB}}$ contents, not to mistake with the zones of iron reduction.

Table 2. AMS ${ }^{14} \mathrm{C}$-ages (yrs BP) and corresponding sedimentation rates $(\mathrm{SR})\left(\mathrm{cm} \mathrm{kyr}^{-1}\right)$

\begin{tabular}{lccc}
\hline Sediment depth $(\mathrm{cm})$ & GeoB 9510 & GeoB 9519 & GeoB 9518 \\
\hline $0-0.5$ & $719 \pm 46$ & $1113 \pm 27$ & $800 \pm 33$ \\
$4-5$ & $1581 \pm 33$ & - & $1345 \pm 28$ \\
$7.5-10$ & $1175 \pm 26$ & $2602 \pm 25$ & $2549 \pm 24$ \\
$15-20$ & $3200 \pm 25$ & $2660 \pm 25$ & $2290 \pm 25$ \\
SR & $\sim 6$ & $\sim 9$ & $\sim 7$ \\
\hline
\end{tabular}

with increasing sediment depth amounts to $42-50 \%$, an observation which has already been documented for continental margin sediments (Anschutz et al., 1998). However, the local maxima in the upper sediment column (in 1.5 to $2.0 \mathrm{~cm}$ ) are parallel to the distribution of $\mathrm{Fe}(\mathrm{III})$-bound $\mathrm{P}$ (i.e. $\mathrm{P}_{\mathrm{CDB}}$, Fig. 4).

Total organic carbon $\left(\mathrm{C}_{\text {org }}\right)$ and total carbonate contents remain relatively constant in all three cores (Fig. 5a). However, maxima in $\mathrm{C}_{\text {org }}$ occur at the sediment surface (1.8 to $3.2 \mathrm{wt} \%)$, and the carbonate content increases slightly with depth (max. 10.1 to $15.2 \mathrm{wt} \%$, data not shown). The molar $\mathrm{C}_{\text {org }}: \mathrm{P}_{\text {org }}$ ratios are generally high with values of up to 500 for instance at site GeoB 9518 (Fig. 5b).

Radiocarbon dating of total organic carbon reveals that all dated sediment constituents are of Holocene age $\left({ }^{14} \mathrm{C}\right.$ ages $<3200 \mathrm{yr}$ BP; Table 2). Data from the $7.5-10 \mathrm{~cm}$ interval deviate from a continuous linear increases in ages with increasing sediment depths. Although we cannot validate our assumption by additional measurements (e.g. ${ }^{210} \mathrm{~Pb}$ ), unfortunately, we interpret this scatter to be related to bioturbative processes. No visual indications for slumping or turbidity events could be observed ( $\mathrm{R}$. Tjallingii, personal communication, 2005). Regardless of reversal gradients, gen- eral trends allow rough estimations of average sedimentation rates (SR). We are aware of this weakness, but approximations for SR between 6 and $9 \mathrm{~cm} \mathrm{kyr}^{-1}$ are in a very good correspondence with age models from adjacent cores (Sarnthein et al., 1994; Mulitza et al., 2008). So, uncertainties of SR estimates may be in a narrow range. However, our modelling results and general, subsequent conclusions are hardly affected by possible variations in SR calculations.

\section{Discussion}

\subsection{The benthic $P$ and Fe cycle - sources and sinks}

The first downward increase of pore water phosphate under oxic conditions (oxygen penetration is estimated to be about $1 \mathrm{~cm}$; Wenzhöfer and Glud, 2002) is attributed to microbially mediated organic matter mineralization (e.g. Froelich et al., 1979; Jahnke et al., 1989). The total release of phosphate by this process is hard to quantify, because the consumption of major electron acceptors like oxygen or nitrate cannot be attributed to the microbial oxidation of organic substance exclusively. Reoxidation of reduced species has to be taken into consideration, although this may be of less quantitative importance in most environments. A probably more significant uncertainty exists on the composition of the organic matter itself or rather of the portion which is degraded. It is striking that our $\mathrm{C}_{\text {org }}: \mathrm{P}_{\text {org }}$ ratios of $300-400$ for the three cores (Fig. 5b) are far beyond the primary composition of the organic matter generally produced in the euphotic zone (106140:1; Redfield et al., 1963; Takahashi et al., 1985). These findings correspond to those from other studies (e.g. Ingall and Van Cappellen, 1990; Anderson et al., 2001). Accordingly, such high ratios may document enhanced regeneration and removal of labile particulate $\mathrm{P}$ relative to organic carbon. The remains, which are preserved in the sediments 
Table 3. Release rates of phosphate $(\mathrm{P})$ and ferrous iron $(\mathrm{Fe})$ as calculated from diffusive fluxes $\left(\mathrm{mmol} \mathrm{m}^{-2} \mathrm{yr}^{-1}\right)$.

\begin{tabular}{lccc}
\hline Benthic nutrient fluxes & GeoB 9510 & GeoB 9519 & GeoB 9518 \\
\hline Release of P during oxic degradation of organic matter & n.d.* & $1.2^{\mathrm{a}}-3.8^{\mathrm{b}}$ & $1.7^{\mathrm{a}}-5.7^{\mathrm{b}}$ \\
Release of P during denitrification & $0.23^{\mathrm{a}}-0.77^{\mathrm{b}}$ & $0.19^{\mathrm{a}}-0.62^{\mathrm{b}}$ & $0.20^{\mathrm{a}}-0.65^{\mathrm{b}}$ \\
Total release of P during reductive dissolution of iron (oxyhydr)oxides & n.d.* & 3.54 & 4.50 \\
Release of P from organic matter during iron reduction & n.d. & $0.010^{\mathrm{a}}-0.033^{\mathrm{b}}$ & $0.012^{\mathrm{a}}-0.031^{\mathrm{b}}$ \\
Release of Fe during reductive dissolution of iron (oxyhydr)oxides & n.d. & 14.03 & 12.95 \\
\hline
\end{tabular}

${ }^{\text {a }} \mathrm{C}_{\text {org }}: \mathrm{P}_{\text {org }}=350$ (mean; cf. Fig. 5b)

${ }^{\mathrm{b}} \mathrm{C}_{\text {org }}: \mathrm{P}_{\text {org }}=106$ (cf. Redfield et al., 1963)

* calculation impossible on account of artificial data

after preferential $\mathrm{P}$ (and $\mathrm{N}$ ) depletion, are a relatively refractory organic component. However, despite the observed impoverishment of the organic substance, $\mathrm{P}_{\text {org }}$ concentrations slightly decrease close to the sediment surface (Fig. 3) and our pore water data indicate a permanent, net phosphate release from organic matter to the pore water within the uppermost $8 \mathrm{~cm}$ (Fig. 2). Oxygen respiration, denitrification, manganese and iron reduction all may contribute to the phosphate release from organic substances. Whereas, almost constant dissolved total sulphur concentrations may indicate that sulphate reduction can be neglected at all three sites.

To estimate the single portions as well as the total rates, geochemical transport and reaction models have been used successfully (e.g. Slomp et al., 1996; Hensen et al., 1997). By comparison of the specific diffusive flux rates at site GeoB 9519 exemplarily (cf. Table 3) our data indicates that the phosphate release from organic matter may occur predominantly via the oxic pathway $(85 \%)$, followed by denitrification $(14 \%)$ in the upper few centimetres of the sediment. According to the simple calculation, the contribution of iron and manganese reduction attributed to organic matter degradation together is only $1 \%$. This small value corresponds perfectly to the slight increase of ammonium concentrations just at depth of iron reduction (Fig. 2). As mentioned before, release rates of $\mathrm{P}_{\text {org }}$ depend on the $\mathrm{C}: \mathrm{P}$ ratio of the organic substrate decomposed. Assuming a constant $\mathrm{C}_{\text {org }}: \mathrm{P}_{\text {org }}$ ratio of 350 (Fig. 5b), in total $1.39 \mathrm{mmolP}_{\mathrm{org}} \mathrm{m}^{-2} \mathrm{yr}^{-1}$ would be released within the uppermost sediment layers at site GeoB 9519. The estimate connected with the modelled respiration of oxygen alone $\left(1.2 \mathrm{mmol} \mathrm{P}_{\mathrm{org}} \mathrm{m}^{-2} \mathrm{yr}^{-1}\right)$ is in very good correspondence with similar previous studies (e.g. Slomp et al., 1996). However, indicated by the virtually absence of phosphate concentration peaks, or at least significant changes in gradients within the uppermost $3 \mathrm{~cm}$ (Fig. 2), pore water data give also clear evidence that $\mathrm{P}_{\text {org }}$ can only be of relatively minor importance for the total dissolved phosphate pool at sites GeoB 9519 and 9518. Obviously, the major $\mathrm{P}$ release is closely associated with the reduction of iron (oxyhydr)oxides (cf. e.g. Krom and Berner, 1981; Sundby et al., 1992; Jensen et al., 1995; Slomp et al.,
1998). Even with conservative calculations of about 4.5 and $3.5 \mathrm{mmol} \mathrm{P} \mathrm{m}^{-2} \mathrm{yr}^{-1}$, respectively, release rates are much higher than estimates for the contribution of $\mathrm{P}_{\text {org }}$ to pore water phosphate (Table 3)

Beside the diffusive exchange across the sediment water interface, phosphate is removed from interstitial waters by association to iron (oxyhydr)oxides. The latter is reflected by the great similarity of phosphate and ferrous iron concentration profiles (Fig. 2; e.g. Krom and Berner, 1980; Lijklema, 1980). Fe minerals are characterized by a high surface area (e.g. Slomp et al., 1996) and high reactivity (e.g. Feely et al., 1990; Poulton and Canfield, 2006). Below the iron reduction zone, iron is probably fixed by the formation of iron sulfides. As depicted in Fig. 5c, total sulphur concentrations increase more than double within the lowermost $10 \mathrm{~cm}$ of all cores, from about $0.2 \mathrm{wt} \%$ within the oxic zone (predominantly representing the sulphur amount in sulphate) to more than $0.4 \mathrm{wt} \%$ at $18 \mathrm{~cm}$ sediment depth. However, the general increase of the total iron concentration with sediment depth (Fig. 4) in this area has recently been attributed to temporal decrease in the primary terrigenous input to these sediments during the last few thousand years (Mulitza et al., 2008).

\subsection{Examination of the benthic budgets}

A major question for the interpretation of geochemical data usually is, if the analysed data set is representative for a system under steady state at the time of sampling. This is of particular interest when specific transfer rates are calculated (or measured) to estimate their importance on time periods of hundreds or thousands of years. For marine sediments, this general question can be reworded into: Is there a balance between the transfer/transport processes as indicated by pore water concentration profiles (or direct rate measurements) and the composition of the sediment?

For our study sites, non-steady state conditions, caused by active venting, significant vertical movement of redox boundaries relative to the sediment surface, and temporal changes in bottom water oxygen concentration can be disregarded. As a very probable approximation we will assume that steady state occurred, at least on moderate time scales 
Table 4. Simplified budget of transfer rates connected with the reduction of iron (oxyhydr)oxides assuming steady state $\mathrm{Fe}^{2+}$ release/precipitation rates; with dry bulk density: $0.4\left(\mathrm{~g} \mathrm{~cm}^{-3}\right)$.

\begin{tabular}{|c|c|c|c|c|}
\hline Parameter & Unit & GeoB 9510 & GeoB 9519 & GeoB 9518 \\
\hline Age of a $2 \mathrm{~cm}$ interval $(\Delta \mathrm{t})$ & yrs & 333 & 222 & 286 \\
\hline $\begin{array}{l}\mathrm{Fe}_{\mathrm{CDB}} \text { decrease within this interval at } \\
\text { depth of iron reduction (Fig. } 5 \mathrm{~d} \text { ) }\end{array}$ & $\begin{array}{l}\mathrm{g} \mathrm{kg}^{-1} \Delta \mathrm{t}^{-1} \\
\mathrm{mg} \mathrm{cm}^{-3} \Delta \mathrm{t}^{-1}\end{array}$ & 2.10 .8 & 1.80 .7 & 1.40 .6 \\
\hline $\mathrm{Fe}^{2+}$ release (cf. Table 3 ) & $\mathrm{mg} \mathrm{cm}^{-3} \Delta \mathrm{t}^{-1}$ & n.d.* & 5.6 & 6.7 \\
\hline $\mathrm{Fe}^{2+}$ re-oxidation & $\mathrm{mg} \mathrm{cm}^{-3} \Delta \mathrm{t}^{-1}$ & n.d. ${ }^{*}$ & 4.0 & 5.0 \\
\hline $\mathrm{Fe}_{\mathrm{CDB}}$ max. - surface & $\mathrm{g} \mathrm{kg}^{-1} \Delta \mathrm{t}^{-1}$ & 0.9 & 0.7 & 0.4 \\
\hline
\end{tabular}

* calculation impossible on account of artificial data

(i.e. several 1000 years). But, considering that a clear decreasing $\mathrm{C}_{\text {org }}$ content versus sediment depth is not observed, and our radio carbon data display differences of detail in gradients in particular at site GeoB 9510 and GeoB 9518, give indication for bioturbative benthic activity throughout the entire sediment column (cf. Fig. 5a; Table 2; e.g. Jahnke et al., 1986; Alperin et al., 1999).

There is a sufficiently consistent picture in consideration of $\mathrm{Fe}$ and $\mathrm{P}$ extraction and pore-water results. For instance, Slomp et al. (1996) suggest that almost similar ratios in both dissolved and particulate $\mathrm{P}$ and $\mathrm{Fe}$ support indication for preferential release into pore water from reductive iron dissolution, which is not the case in our study. While the Fe:P ratios of the CDB-extractable mineral fraction at the depth of iron reduction show values in a range already described in deep-sea sediments (24.4 to 32.0, Figs. 4 and 5d; Anschutz et al., 1998; Van der Zee et al., 2005), the distributions of solutes at site GeoB 9519 and GeoB 9518 indicate that the release of ferrous iron is only 4.0 to 2.9 times higher, respectively, than for phosphate (i.e. low $\mathrm{Fe}(\mathrm{II}): \mathrm{PO}_{4}^{2}$, Table 3). Furthermore, based on the stoichiometric range for the microbially catalyzed reduction of iron (oxyhydr)oxides, the degradation of organic matter during this process cannot be a significant additional source for pore water phosphate (0.3$0.7 \%$ of the total phosphate release; Table 3 ). Even if the iron oxides, newly formed in the oxic zone, are very fine grained, poorly crystalline, and easily reducible, it seems very unlikely that such extremely low values of total phosphate release during iron reduction correspond to the ratios of the reduced mineral phase. This would be in contradiction to all reported knowledge on specific surface areas and adsorption capacities for iron oxides (Borggard, 1983; Crosby et al., 1983). A possible explanation could be a limited "etching" of mineral surfaces with their high phosphate covering density before the real crystal lattice is affected. Nevertheless, assuming steady state conditions, simple budget calculations reveal that the investigated pore water system cannot be balanced by diffusive transport and sediment accumulation alone. Certainly, under idealized conditions, local maxima, decreases or even total depletions in specific sedi- ment $\mathrm{Fe}$ fractions should correspond to appropriate sinks and sources as indicated by the distribution of dissolved components. But the available amounts of mineral phases are by far not sufficient to maintain the diffusive flux or rather transfer rates for longer times. The downward decreases in $\mathrm{Fe}_{\mathrm{CDB}}$ of 1.8 to $1.4 \mathrm{~g} \mathrm{~kg}^{-1}$ within an about $2 \mathrm{~cm}$ thick layer, are clearly caused by the reductive dissolution of iron (oxyhyxdr)oxides (Fig. 5d, grey bar) which follows below (cf. Fig. 2). Only by conservative burial due to simple accumulation onto sea floor, particles would pass this depth interval within a period of about 220-330 years, depending on the local sedimentation rate (Table 2). At sites GeoB 9519 and GeoB 9518, release rates of $\mathrm{Fe}^{2+}$, constant for these periods, would require a demand of 5.6 and $6.7 \mathrm{mg} \mathrm{cm}^{-3}$ reducible iron oxides, respectively. These numbers are about 8 to 11 times higher than the detected decreases in $\mathrm{Fe}_{\mathrm{CDB}}$. Appropriate calculations for the re-oxidation of ferrous iron within the surface layer above iron reduction zone lead to similar results (Table 4). This calculated deficit of iron (oxyhyxdr)oxides would even be higher if oxidation of mineral Fe(II) phases should have occurred during oxic pretreatment of our samples (cf. Sect. 2.4).

The apparent discrepancy gets clearly visible when modelling the pore water concentration profiles by fitting the underlying transfer rates. The distribution of ferrous iron and iron mineral phases at site GeoB 9519 clearly illustrates this (Fig. 6). Negative values for transfer rates imply the release of iron (due to reductive dissolution), and positive values are equal to the fixation of dissolved iron (above: due to reoxidation, below: probably due to the formation of iron sulphides). If molecular diffusion and sediment accumulation would be the only controlling factors for the benthic iron (and phosphate) cycle, both, the surface near enrichment of (oxyhydr)oxides and the depletion of iron within the iron reduction zone have had to be much more pronounced under the assumption of steady-state conditions. However, total iron concentrations are comparatively constant from 3 to $6 \mathrm{~cm}$ depth in GeoB 9519. Slight increases below $6 \mathrm{~cm}$ can be rather assigned to temporal changes in the terrigenous input than to effects of early diagenesis. However, obviously an 


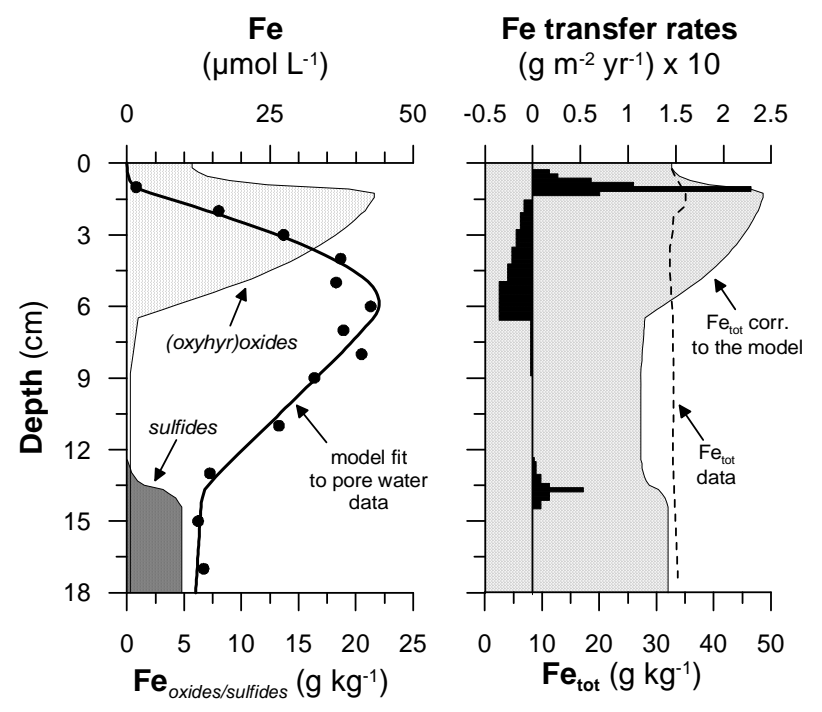

Fig. 6. Left: model fit to ferrous iron profile at site GeoB 9519 in comparison to the distribution of particulate iron mineral phases ( $\left.\mathrm{Fe}_{\text {oxides/sulfides }}\right)$. Right: distribution of iron mineral phases $\left(\mathrm{Fe}_{\text {tot }}\right.$, $\mathrm{Fe}_{\text {tot }}$ corrected to model fit) and transfer rates (negative values: release due to reductive dissolution; positive values: fixation of dissolved iron).

additional transport process is required to explain our $\mathrm{P}_{\mathrm{CDB}}$ and $\mathrm{Fe}_{\mathrm{CDB}}$ data (Fig. 4). This additional process can only be a net downward transport of P-associated to iron (oxyhydr)oxides. Such an active internal replacement and cycling of particulate matter could be caused by bioturbation, at least occasionally (e.g. Boudreau and Jørgensen, 2001 and refs. therein). Supported by results of one-dimensional reactiontransport modelling, Slomp et al. (1998) have already argued in a similar way the effects of bioturbation. The close correspondence between observed depth integrated iron content (Figs. 4 and 5d) and its distribution deduced from transfer rates (Fig. 6), gives additional support to our interpretation. Anyway, if release and precipitation rates occur in the range as indicated by pore water data and if these rates seem constant over time, physical sediment mixing is an essential process to maintain a steady-state situation in the observed system.

\section{Conclusions}

Controlling processes for the benthic $\mathrm{P}$ and $\mathrm{Fe}$ cycles in marine surface sediments were investigated by means of pore water and solid phase analysis, balancing of release and precipitation rates and the approach of a simple one-dimensional transport-reaction model. Biogenic, Fe(III)-, and organicbound fractions are identified as the most important $\mathrm{P}$ pools in these sediments. Calculations of transfer rates reveal that most of the dissolved phosphate is recently released to interstitial waters during the reduction of iron (oxyhydr)oxides.
Comparing between release and precipitation rates, however, an apparent discrepancy is observed in the distribution of both sedimentary constituents. This balance approach clearly indicates the importance of particle mixing (bioturbation) for the maintenance of such system.

Acknowledgements. We want to thank the captain and crew of RV Meteor for their support during cruise M65/1. We highly appreciate the technical help onboard by C. März, S. Wiesmaier and S. Pape. We further want to thank B. Kockisch for TOC measurements and S. Pape, S. Siemer, N. Allroggen for sample preparation and lab assistance. Last but not least, we thank R. Jahnke, K. Küsel, and two anonymous reviewers for their very helpful and constructive support. This study was financed by the DFG International Graduate College EUROPROX.

Edited by: K. Küsel

\section{References}

Alperin, M. J., Martens, C. S., Albert, D. B., Suayah, I. B., Benninger, L. K., Blair, N. E., and Jahnke, R. A.: Benthic fluxes and pore water concentration profiles of dissolved organic carbon in sediments from the North Carolina continental slope, Geochim. Cosmochim. Ac., 63, 427-448, 1999.

Anderson, L. D., Delaney, M. L., and Faul, K. L.: Carbon to phosphorus ratios in sediments: Implications for nutrient cycling, Global Biogeochem. Cy., 15, 65-79, 2001.

Anderson, L. G., Turner, D. R., Wedburg, M., and Dyrssen, D.: Determination of total alkalinity and total dissolved inorganic carbon, in: Methods of Seawater Analysis, 3. Edn., edited by: Grasshoff, K., Kremling, K., and Ehrhardt, M., Wiley-VCH, Weinheim, 127-148, 1999.

Anschutz, P., Zhong, S., Sundby, B., Mucci, A., and Gobeil, C.: Burial efficiency of phosphorus and the geochemistry of iron in continental margin sediments, Limnol. Oceanogr., 43, 53-64, 1998.

Barusseau, J. P., Giresse, P., Faure, H., Lezine, A. M., and Masse, J. P.: Marine sedimentary environments on some parts of the tropical and equatorial Atlantic margins of Africa during Late Quaternary, Cont. Shelf Res., 8, 1-21, 1988.

Baturin, G. N.: Phosphorites on the sea floor. Origin, composition and distribution, Elsevier, Amsterdam, 343 pp., 1982.

Borggard, O. K.: Effect of surface area and mineralogy of iron oxides on their surface charge and anion-adsorption properties, Clays Clay Min., 31, 230-232, 1983.

Boudreau, B. P. and Jørgensen, B. B.: The benthic boundary layer: transport processes and biogeochemistry, Oxfort University Press, US, 404 pp., 2001.

Burns, S. J.: Early diagenesis in Amazon Fan sediments, in: Proc. ODP Sci. Results, edited by: Flood, R. D., Piper, D. J. W., Klaus, A., and Peterson, L. C., College Station, Texas, 497-504, 1997.

Crosby, S. A., Glasson, D. R., Cuttler, A. H., Butler, I., Turner, D. R., Whitfield, M., and Millward, G. E.: Surface areas and porosities of $\mathrm{Fe}(\mathrm{III})-\mathrm{Fe}(\mathrm{II})$-derived oxyhydroxides, Environ. Sci. Technol., 17, 709-713, 1983.

De Lange, G. J., Cranston, R. E., Hydes, D. H., and Boust D.: Extraction of pore water from marine sediments: A review of pos- 
sible artifacts with pertinent examples from the North Atlantic, Mar. Geol., 109, 53-76, 1992.

De Lange, G. J.: Distribution of various extracted phosphorus compounds in the interbedded turbiditic/pelagic sediments of the Madeira Abyssal Plain, eastern North Atlantic, Mar. Geol., 109, 115-139, 1992.

Dickens, G. R., Koelling, M., Smith, D. C., Schnieders, L., and Scientists: Rhizon Sampling of Pore Waters on Scientific Drilling Expeditions: An Example from the IODP Expedition 302, artic coring expedition (ACEX), Scientific Drilling, 4, 22-25, 2007.

Fagel, N., Alleman, L. Y., Granina, L., Hatert, F., Thamo-Boszo, E., Cloots, R., and André, L.: Vivianite formation and distribution in Lake Baikal sediments, Global Planet. Change, 46, 315-336, 2005.

Feely, R. A., Massoth, G. J., Baker, E. T., Cowen, J. P., Lamb, M. F., and Krogslund, K. A.: The effect of hydrothermal processes on midwater phosphorus distributions in the northeast Pacific, Earth Planet. Sci. Lett., 96, 305-318, 1990.

Föllmi, K. B.: The phosphorus cycle, phosphogenesis and marine phosphate-rich deposits, Earth-Sci. Rev., 40, 55-124, 1996.

Froelich, P. N., Klinkhammer, G. P., Bender, M. L., Luedtke, N. A., Heath, G. R., Cullen, D., Dauphin, P., Hammond, D., Hartman, B., and Maynard, V.: Early oxidation of organic matter in pelagic sediments of the eastern equatorial Atlantic: suboxic diagenesis, Geochim. Cosmochim. Ac., 43, 1075-1090, 1979.

Froelich, P. N., Arthur, M. A., Burnett, W. C., Deakin, M., Hensley, V., Jahnke, R., Kaul, L., Kim, K.-H., Roe, K., Soutar, A., and Vathakanon, C.: Early diagenesis of organic matter in Peru continental margin sediments: Phosphorite precipitation, Mar. Geol., 80, 309-343, 1988.

Hagen, E.: Mesoscale upwelling variations off the West African coast, in: Coastal and Estuarine Sciences, Coastal Upwelling, 1. Edn., edited by: Richards, F. A., AGU, Washington DC, 7278, 1981.

Hagen, E.: Northwest African upwelling scenario, Oceanol. Acta, 24, 113-128, 2000.

Hall, P. O. J. and Aller, R. C.: Rapid, small-volume, flow injection analysis for $\delta \mathrm{CO}_{2}$, and $\mathrm{NH}_{4}^{+}$in marine and freshwaters, Limnol. Oceanogr., 37, 1113-1119, 1992.

Hammond, D. E., Giordani, P., Berelson, W. M., and Poletti, R.: Diagenesis of carbon and nutrients and benthic exchange in sediments of the Northern Adriatic Sea, Mar. Chem., 66, 53-97, 1999.

Hansen, H. P. and Koroleff, F.: Determination of nutrients, in: Methods in Seawater Analysis, 3rd edition, edited by: Grasshoff, K., Ehrhardt, M., and Kremling, K., Wiley-VCH, Weinheim, 159-228, 1999.

Hartmann, M. P., Müller, P. J., Suess, E., and Van der Weijden, C. H.: Chemistry of Late Quaternary sediments and their interstitial waters from the NW African continental margin, Meteor Forschungsergebnisse Ser. C, Hamburg, 24, 1-67, 1976.

Helmke, P., Romero, O., and Fischer, G.: Northwest African upwelling and its effect on offshore organic carbon export to the deep sea, Global Biogeochem. Cy., 19, 1-15, doi:10.1029/2004GB002265, 2005.

Hensen, C., Landenberger, H., Zabel, M., Gundersen, J. K., Glud, R. N., and Schulz, H. D.: Simulation of early diagenetic processes in continental slope sediments off southwest Africa: the computer model CoTAM tested, Mar. Geol., 144, 191-210,
1997.

Hensen, C., Landenberger, H., Zabel, M., and Schulz, H. D.: Quantification of diffusive benthic fluxes of nitrate, phosphate and silicate in the South Atlantic Ocean, Global Biogeochem. Cy., 12, 277-300, 1998.

Ingall, E. D. and Van Cappellen, P.: Relation between sedimentation rate and burial of organic phosphorus and organic carbon in marine sediments, Geochim. Cosmochim. Ac., 54, 373-386, 1990.

Ingall, E. D. and Jahnke, R.: Evidence for enhanced phosphorus regeneration from marine sediments overlain by oxygen depleted waters, Geochim. Cosmochim. Ac., 58, 2571-2575, 1994.

Inthorn, M., Wagner, T., Scheeder, G., and Zabel, M.: Lateral transport controls distribution, quality, and burial of organic matter along continental slopes in high-productivity areas, Geology, 34, 205-208, 2006.

Jahnke, R. A., Emerson, S. R., Cochran, J. K., and Hirschberg, D. J.: Fine scale distributions of porosity and particle excess ${ }^{210} \mathrm{~Pb}$, organic carbon and $\mathrm{CaCO}_{3}$ in surface sediments of the deep equatorial Pacific, Earth Planet. Sci. Lett., 77, 59-69, 1986.

Jahnke, R. A., Emerson, S. R., Reimers, C. E., Schuffert, J., Ruttenberg, K. C., and Archer, D.: Benthic recycling of biogenic debris in eastern equatorial Atlantic Ocean, Geochim. Cosmochim. Ac. 53, 2947-2960, 1989.

Jensen, H. S., Mortensen, P. B., Andersen, F. O., Rasmussen, E., and Jensen, A.: Phosphorus cycling in a coastal marine sediment, Aarhus Bay, Denmark, Limnol. Oceanogr., 40, 908-917, 1995.

Kim, D., Schuffert, J. D., and Kastner, M.: Francolite authigenesis in california continental slope sediments and its implications for the marine P cycle, Geochim. Cosmochim. Acta, 63, 3477-3485, 1999.

Koroleff, F. and Kremling, K.: Determination of trace elements Analysis by spectrophotometry, in: Methods of Seawater Analysis, 3. Edn., edited by: Grasshoff, K., Kremling, K., and Ehrhardt, M., Wiley-VCH, Weinheim, 340-344, 1999.

Krom, M. D. and Berner, R. A.: Adsorption of phosphate in anoxic marine sediments, Limnol. Oceanogr., 25, 797-806, 1980.

Krom, M. D. and Berner, R. A.: The diagenesis of phosphorus in a nearshore sediment, Geochim. Cosmochim. Ac., 45, 207-216, 1981.

Latimer, J. C., Filippelli, G. M., Hendy, I., and Newkirk, D. R.: Opal-associated particulate phosphorus: Implications for the marine P cycle, Geochim. Cosmochim. Ac., 70, 3843-3854, 2006.

Lerman, A.: Geochemical Processes: Water and sediment environments, Wiley-VCH, New York, 481 pp., 1979.

Li, Y.-H. and Gregory, S.: Diffusion of ions in sea water and in deep-sea sediments, Geochim. Cosmochim. Ac., 38, 703-714, 1974.

Lijklema, L.: Interaction of orthophosphate with iron(III) and aluminum hydroxides, Environ. Sci. Technol., 14, 537-541, 1980.

Lutze, G. F. and Coulbourn, W. T.: Recent benthic foraminifera from the continental margin of northwest Africa: Community structure and distribution, Mar. Micropaleontol., 8, 361-401, 1984.

März, C., Hoffmann, J., Bleil, U., De Lange, G. J., and Kasten, S.: Diagenetic changes of magnetic and geochemical signals by anaerobic methan oxidation in sediments of the Zambesi deepsea fan (SW Indian Ocean), Mar. Geol., 255, 118-130, 2008.

McMaster, R. L. and Lachance, T. P.: Northwestern African conti- 
nental shelf sediments, Mar. Geol., 7, 57-67, 1969.

Mittelstaedt, E.: The upwelling area off Northwest Africa - A description of phenomena related to coastal upwelling, Prog. Oceanogr., 12, 307-331, 1983.

Mollenhauer, G., Inthorn, M., Vogt, T., Zabel, M., Sinninghe Damste, J. S., and Eglinton, T. I.: Aging of marine organic matter during cross-shelf lateral transport in the Benguela upwelling system revealed by compound-specific radiocarbon dating, Geochem. Geophys. Geosyst., 8, Q09004, doi:09010.01029/02007GC001603, 2007.

Mulitza, S., and cruise participants: Report and preliminary results of Meteor cruise M65/1, Dakar - Dakar, 11.06.-1.07.2005, Berichte FB Geowissenschaften der Universität Bremen, Bremen, 252, 149 pp., 2006.

Mulitza, S., Prange, M., Stuut, J.-B., Zabel, M., Dobeneck, T. v., Intambi, C., Nizou, J., and Schulz, M.: Sahel megadroughts triggered by glacial slowdowns of Atlantic meridional overturning, Paleoceanogr., 23, doi:10.1029/2008PA001637, 2008.

Nadeau, M. J., Schleicher, M., Grootes, P. M., Erlenkeuser, H., Gottdang, A., Mous, D. J. W., Sarnthein, J. M., and Willkomm, H.: The Leibniz-Labor AMS facility at the Christian-Albrechts University, Kiel, Germany, Nucl. Instrum. Methods Phys. Res. Sec. B, 123, 22-30, 1997.

Poulton, S. W. and Canfield, D. E.: Co-diagenesis of iron and phosphorus in hydrothermal sediments from the southern East Pacific Rise: Implications for the evaluation of paleoseawater phosphate concentrations, Geochim. Cosmochim. Ac., 70, 58835898, 2006.

Redfield, A. C., Ketchum, B. H., and Richards, F. A.: The influence of organisms in the composition of sea-water, in: The composition of seawater. Comparative and descriptive oceanography, 1st edition, edited by: Hill, M. N., Interscience, New York, 26-77, 1963.

Ruttenberg, K. C.: Development of a sequential extraction method for different forms of phosphorus in marine sediments, Limnol. Oceanogr., 37, 1460-1482, 1992.

Sarnthein, M., Winn, K., Jung, S. J. A., Duplessy, J.-C., Labeyrie, L., Erlenkeuser, H., and Ganssen, G. M.: Changes in east Atlantic deepwater circulation over the last 30,000 years: Eight time slice reconstructions, Paleoceanography, 9(2), 209-267, 1994.

Sarnthein, M.: Sedimentology on sediment core GIK 13239-1, http: //doi.pangaea.de/ 10.1594/PANGAEA.134606, 2004.

Schenau, S. J. and De Lange, G. J.: A novel chemical method to quantify fish debris in marine sediments, Limnol. Oceanogr., 45, 963-971, 2000.

Schenau, S. J., Slomp, C. P., and De Lange, G. J.: Phosphogenesis and active phosphorite formation in sediments from the Arabian Sea oxygen minimum zone, Mar. Geol., 169, 1-20, 2000.

Schenau, S. J. and De Lange, G. J.: Phosphorus regeneration vs. burial in sediments of the Arabian Sea, Mar. Chem., 75, 201217, 2001.

Schlichting, A. and Leinweber, P.: Effects of pretreatment on sequentially-extracted phosphorus fractions from peat soils, Commun. Soil Sci. Plant Anal., 33, 1617-1627, 2002.

Schulz, H. D. and Schulz, H. N.: Large Sulfur Bacteria and the Formation of Phosphorite, Science, 307, 416-418, 2005.
Schulz, H. D.: Quantification of Early Diagenesis: Dissolved Constituents in Pore Water and Signals in the Solid phase, in: Marine Geochemistry, 2. Edn., edited by: Schulz, H. D. and Zabel, M., Springer-Verlag, Berlin, Heidelberg, New York, 75-124, 2006 a.

Schulz, H. D.: Conceptual Models and Computer Models, in: Marine Geochemistry, 2. Edn., edited by: Schulz, H. D. and Zabel, M., Springer-Verlag, Berlin, Heidelberg, New York, 513-547, 2006b.

Seeberg-Elverfeldt, J., Schlüter, M., Feseker, T., and Kölling, M.: Rhizon sampling of porewaters near the sediment-water interface in aquatic systems, Limn. Oceanogr. Methods, 3, 361-371, 2005.

Slomp, C. P., Epping, E. H. G., Helder, W., and Van Raaphorst, W.: A key role for iron-bound phosphorus in authigenc apatite formation in North Atlantic continental platform sediments, J. Mar. Res., 54, 1179-1205, 1996.

Slomp, C. P., Malschaert, J. F. P., and Van Raaphorst, W.: The role of adsorption in sediment-water exchange of phosphate in North Sea continental margin sediments, Limnol. Oceanogr., 43, 832846, 1998.

Strickland, J. D. H. and Parsons, T. R.: A practical handbook of seawater analysis, Fisheries Research Board of Cananda, Ottawa, 293 pp., 1968.

Summerhayes, C. P.: Sedimentation of organic matter in upwelling regimes, in: Coastal upwelling - Its Sediments Record Part B: Sedimentary records of ancient coastal upwelling, 1. Edn., edited by: Suess, E., and Thiede, J., Plenum Press, New York, 29-72, 1983.

Sundby, B., Gobeil, C., Silverberg, N., and Mucci, A.: The phosphorus cycle in coastal marine sediments, Limnol. Oceanogr., 37, 1129-1145, 1992.

Takahashi, T., Broecker, W. S., and Langer, S.: Redfield Ratio based on chemical data from isopycnal surfaces, J. Geophys. Res., 90, 6907-6924, 1985.

Van Cappellen, P. and Ingall, E. D.: Benthic phophorus regeneration, net primary production, and ocean anoxia: A model of the coupled marine biogeochemical cycles of carbon and phosphorus, Paleoceanography, 9, 677-692, 1994.

Van der Zee, C., Slomp, C. P., Rancourt, D. G., De Lange, G. J., and Van Raaphorst, W.: A Mössbauer spectroscopic study of the iron redox transition in eastern Mediterranean sediments, Geochim. Cosmochim. Ac., 69, 441-453, 2005.

Wenzhöfer, F. and Glud, R. N.: Benthic carbon mineralization in the Atlantic: a synthesis based on in situ data from the last decades, Deep-Sea Res. Pt. I, 49, 1255-1279, 2002.

Zabel, M., Dahmke, A., and Schulz, H. D.: Regional distribution of diffusive phosphate and silicate fluxes through the sedimentwater interface: the eastern South Atlantic, Deep-Sea Res. Pt. I, 45, 277-300, 1998.

Zabel, M., Bickert, T., Dittert, L., and Haese, R. R.: The significance of the sedimentary $\mathrm{Al} / \mathrm{Ti}$ ratio as indicator for reconstructions of terrestrial input to the equatorial Atlantic, Paleoceanography, 14, 789-799, 1999.

Zabel, M. and Schulz, H. D.: Importance of submarine landslides for non-steady state conditions in pore water systems - lower Zaire (Congo) deep-sea fan, Mar. Geol., 176, 87-99, 2001. 